\title{
Sand Fly-Associated Phlebovirus with Evidence of Neutralizing Antibodies in Humans, Kenya
}

\author{
David P. Tchouassi, Marco Marklewitz, Edith Chepkorir, Florian Zirkel, ${ }^{1}$ \\ Sheila B. Agha, Caroline C. Tigoi, Edith Koskei, Christian Drosten, \\ Christian Borgemeister, Baldwyn Torto, Sandra Junglen, ${ }^{2}$ Rosemary Sang ${ }^{2}$
}

We describe a novel virus, designated Ntepes virus (NPV), isolated from sand flies in Kenya. NPV has the characteristic phlebovirus trisegmented genome architecture and is related to, but distinct from, Gabek Forest phlebovirus. Diverse cell cultures derived from wildlife, livestock, and humans were susceptible to NPV, with pronounced permissiveness in swine and rodent cells. NPV infection of newborn mice caused rapid and fatal illness. Permissiveness for NPV replication in sand fly cells, but not mosquito cells, suggests a vector-specific adaptation. Specific neutralizing antibodies were found in $13.9 \%(26 / 187)$ of human serum samples taken at the site of isolation of NPV as well as a disparate site in northeastern Kenya, suggesting a wide distribution. We identify a novel human-infecting arbovirus and highlight the importance of rural areas in tropical Africa for arbovirus surveillance as well as extending arbovirus surveillance to include hematophagous arthropods other than mosquitoes.

$\mathrm{D}$ isease outbreaks caused by Zika, dengue, yellow fever, chikungunya, and Rift Valley fever viruses illustrate the threat posed by arthropodborne viruses (arboviruses), which affect millions of patients worldwide each year (1-3). Major epidemic arboviruses are thought to have originated in tropical Africa, where they are known or thought to have caused local outbreaks before epidemic or pandemic spread. Early recognition of local outbreaks, including precise identification of the disease-causing agent, is key to effective preparedness against epidemics. However, active surveillance is poorly implemented in most seeding countries.

\footnotetext{
Author affiliations: International Centre of Insect Physiology and Ecology, Nairobi, Kenya (D.P. Tchouassi, E. Chepkorir, S.B. Agha, C.C. Tigoi, B. Torto, R. Sang); Charité-Universitätsmedizin Berlin, Berlin, Germany (M. Marklewitz, F. Zirkel, C. Drosten, S. Junglen); German Center for Infection Research, Berlin (M. Marklewitz,

F. Zirkel, C. Drosten, S. Junglen); Center for Virus Research, Kenya Medical Research Institute, Nairobi (E. Koskei, R. Sang); University of Bonn, Bonn, Germany (C. Borgemeister)
}

DOI: https://doi.org/10.3201/eid2504.180750
Monitoring programs for vectors of arboviral diseases often prioritize mosquitoes and ticks (4), neglecting other blood-feeding vectors, such as sand flies. Sand flies transmit protozoan parasites that cause leishmaniasis as well as phleboviruses (order Bunyavirales, family Phenuiviridae, genus Phlebovirus) $(5,6)$. Sand fly-borne phlebovirus infections are known to occur in the Mediterranean basin $(7,8)$. Some of these, such as sandfly fever Naples, Sicilian, and Toscana viruses, are of public health importance, especially Toscana virus, which causes meningitis and encephalitis in humans $(8-10)$.

The International Committee for the Taxonomy of Viruses (ICTV) currently recognizes 10 viral species within the genus Phlebovirus: Rift Valley fever virus (RVFV), severe fever with thrombocytopenia syndrome (SFTS) virus, Uukuniemi phlebovirus, Bujaru phlebovirus, Candiru phlebovirus, Chilibre phlebovirus, Frijoles phlebovirus, Punta Toro phlebovirus, Salehabad phlebovirus, and sandfly fever Naples phlebovirus (11). The last 7 species are vectored by sand flies. Novel unclassified phleboviruses (e.g., Fermo, Granada, Punique, and Massilia viruses), as well as recently discovered flaviviruses in sand flies, underline the importance of these neglected vectors of arboviral diseases (12-16).

Sand fly-borne phleboviruses have been studied mainly in the Mediterranean region. Prevalence data for sub-Saharan Africa remain scarce. Studies have found serologic evidence of human infections with Karimabad, sandfly fever Naples, and sandfly fever Sicilian viruses in patients from Sudan with febrile illness $(7,17,18)$. Human infections with sandfly fever Naples and Sicilian viruses have been reported in Uganda, Somalia, Djibouti, and Ethiopia $(7,19)$. However, serologic surveys may be compounded by antigenic crossreactivity between phleboviruses (except in neutralization assays), thereby precluding the unequivocal identification of the circulating sand fly-borne virus (5). Few studies have incorporated viral genetic characterization.

${ }^{1}$ Current affiliation: Biotest AG, Dreieich, Germany.

${ }^{2}$ These authors contributed equally to this article. 
We describe a previously unknown phlebovirus discovered during vector surveillance in Kenya, which we designate Ntepes virus (NPV), after the place of sampling of virus-infected sand flies. The complete genome of NPV was sequenced, viral species tropism in cell culture assessed, and pathogenicity in vertebrates proven by infection of mice. Human serum samples from Ntepes and other communities yielded evidence of human infection based on specific virus neutralization.

\section{Methods}

\section{Sandfly Trapping and Virus Isolation}

We trapped sandflies using CDC light traps (John W. Hock, https://johnwhock.com) in villages of the Marigat district, Baringo County, Kenya, in February 2014 (Figure 1). We homogenized pools of 5-50 female specimens in minimum essential medium (MEM), inoculated an aliquot of the clarified supernatant $(50 \mu \mathrm{L})$ into Vero cells, and incubated it for up to 14 days with daily monitoring for cytopathic effect (CPE). We passaged CPE-positive supernatant onto fresh Vero E6/7 cells; virus stock solution was generated from the first passage and used for all further experiments. We determined the infectious titer by $50 \%$ tissue culture infectious dose $\left(\mathrm{TCID}_{50}\right)$ assay using 10 -fold serial dilutions from $10^{-1}$ to $10^{-12}$ of the virus stock inoculated in 5 wells each of subconfluent Vero cells seeded in a 96-well plate. We calculated the virus titer

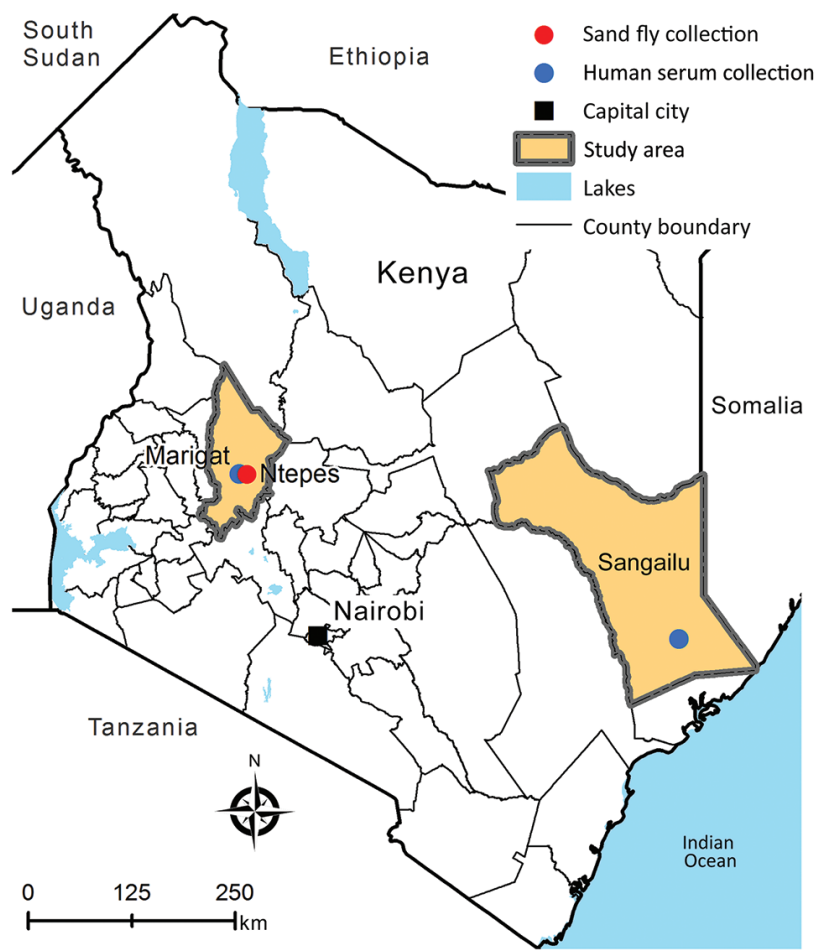

Figure 1. Geographic location of sand fly collection site (Ntepes) and district hospitals of Marigat and Sangailu, where human serum samples were collected, Kenya. according to Reed and Muench (20). We estimated the minimum infection rate (MIR) in sandflies using the formula [number of positive pools/total specimens tested] $\times 1,000$.

\section{Broad Reverse Transcription PCR Screening}

We extracted RNA from cytopathic cell culture supernatant $(200 \mu \mathrm{L}$ aliquot) using the Viral RNA Mini Kit (QIAGEN, https://www.qiagen.com) and eluted it in 50 $\mu \mathrm{L}$ of buffer. We performed cDNA synthesis using SuperScript III reverse transcription (Invitrogen, https://www. thermofisher.com) and random hexamer primers (TIB Molbiol, https://www.tib-molbiol.com), followed by reverse transcription PCR (RT-PCR) for orthobunyaviruses, alphaviruses, and flaviviruses $(21-24)$. We screened for sand fly-borne phleboviruses by targeting the RNA-dependent RNA polymerase (RdRp) gene using degenerate primers (25). We compared the nucleotide sequences to GenBank using blastn (https://blast.ncbi.nlm.nih.gov/Blast.cgi) and subjected them to initial phylogenetic analysis in MEGA6 (20). We further extracted RNA from pooled sand flies and tested it by real-time PCR using NPV-specific primers (forward, 5'-GCAAGAAAGCACTGTGGTGG; reverse, 5'-CGTATGATGATCGGCCACCA; probe, 5'-6-FAMACAGCCACCTCTGATGATGC-IBFQ).

\section{Genotyping of Sand Flies and Blood Meal Analysis}

We amplified the barcode region of the cytochrome $c$ oxidase subunit I (COI) gene using published primers (27). We extracted genomic DNA from individual bloodfed sand fly specimens using the QIAGEN DNeasy Blood and Tissue Kit (QIAGEN). We amplified a 500-bp fragment of the $12 \mathrm{~S}$ mitochondrial rRNA gene as described (28), sequenced the PCR products, and compared them to GenBank database data. We inferred species-level identification on the basis of $\geq 98 \%$ identity spanning $\geq 300 \mathrm{bp}$, as described by Valinsky et al. (29).

\section{Next-Generation Sequencing, Genome Annotation, and Phylogenetics}

We purified and concentrated virions from the supernatant of infected Vero cells by ultracentrifugation through a $36 \%$ sucrose cushion. We extracted viral RNA using the QIAGEN RNeasy Kit according to the manufacturer's instructions. We generated cDNA using the Maxima H Minus Double-Stranded cDNA Synthesis Kit and random hexamer primers (Thermo Fisher Scientific, https://www.thermofisher.com). We prepared DNA libraries using the Nextera XT DNA Sample Preparation Kit and analyzed them on an Illumina MiSeq instrument with the MiSeq Reagent Kit v3 (Illumina, https://www.illumina.com). We identified viral reads by reference mapping to phleboviruses as well as by BLAST comparisons against a local amino acid sequence library containing translations of open reading frames 
(ORFs) of phleboviruses. We closed sequence gaps by conventional RT-PCR followed by Sanger sequencing. We performed genome assembly using Geneious (http://www. geneious.com) and confirmed genome terminal sequences by rapid amplification of cDNA ends (RACE-PCR; Life Technologies, https://www.thermofisher.com). We identified ORFs using Geneious, compared nucleotide and amino acid sequences with other sequences by blastn and blastx searches against the GenBank database, and identified protein motifs by web-based comparison to the Pfam database (http://www.pfam.janelia.org). We identified putative transmembrane regions by prediction of the hydropathy profile using TMHMM (http://www.cbs.dtu.dk/services/ TMHMM-2.0) and predicted N-linked glycosylation sites using the NetNGlyc 1.0 server (http://www.cbs.dtu.dk/services/NetNGlyc).

We aligned nucleotide and amino acid sequences of the ORFs of the respective genome segments with related viral sequences in Geneious using MAFFT (30). Phylogenetic trees were inferred by the maximum-likelihood (ML) method using the best suitable substitution matrix (LG) identified by Modeltest, as implemented in MEGA. We performed confidence testing based on 1,000 bootstrap iterations (31).

\section{In Vitro Viral Growth Kinetics}

We infected cell lines from insects (LL-5, sand fly; C6/36, mosquito), humans (HEK293-T), small mammals (BHK21, hamster; VeroE6/7, primate; MEF, mouse; EidNi, bat), and livestock (PK-15, swine; ZN-R, goat; DF-1, chicken; $\mathrm{KN}-\mathrm{R}$, cattle) in doublets, at a multiplicity of infection of 0.1 . We harvested aliquots of infectious cell culture supernatants every $24 \mathrm{~h}$ for periods of $7 \mathrm{~d}$ and quantified viral genome copies by real-time RT-PCR with plasmid-based quantification standards.

\section{In Vivo Pathogenesis in Suckling Mice}

We intracerebrally inoculated $100 \mu \mathrm{L}$ of the viral stock of the first passage, as well as 3 consecutive 2-fold dilutions, into 3-4-day-old Swiss Albino suckling mice. The doses used in the experimental infection were quantified by plaque assays in Vero cells as described previously (32) and corresponded to viral titers of $4 \times 10^{6}, 2 \times 10^{6}, 1 \times 10^{6}$, $5 \times 10^{5}$, and $2.5 \times 10^{5} \mathrm{PFU} / \mathrm{mL}$. We included noninfectious MEM as a negative control. We observed all mice 2 times/ day for up to 14 days for signs of disease. We homogenized brains from recently dead mice in $1 \mathrm{~mL}$ of cell culture media and plaque-titrated them on Vero cells.

\section{Human Serum Samples and Neutralization Tests}

Archived serum samples from the Marigat district hospital, taken during 2010-2011, and from Sangailu Health Centre in the Hulugho subcounty in northeastern Kenya, collected during 2010-2012, were available (Figure 1). We performed a virus neutralization test using 2-fold serial dilutions of serum samples (1:20 to 1:640). We mixed $50 \mu \mathrm{L}$ of the serial serum dilutions with $70 \mathrm{TCID}_{50}$ of NPV. Mixtures were incubated at $37^{\circ} \mathrm{C}$ in the presence of $5 \% \mathrm{CO}_{2}$ for $1 \mathrm{~h}$, then used for infection of a confluent Vero E6/7 cell monolayer seeded in 96-well culture plates with 2 wells/ dilution. After 7 days of incubation, we recorded the highest serum dilution at which no CPE was observed in at least $50 \%$ of the wells as the neutralization titer.

We tested NPV-reactive human serum samples with RVFV, Gabek Forest virus (GFV), and Karimabad virus (KARV) for serologic cross-reactivity, as described earlier in this article. In addition, we tested GFV- and KARVpositive serum samples with NPV in 2-fold serial dilutions from 1:5 to 1:20 (Table).

\section{Ethics Considerations}

Approval for the study was granted by the Scientific and Ethical Review Unit and Animal Care and Use Committee of the Kenya Medical Research Institute (SSC Protocol nos. 1560 and KEMRI/SERU/CVR/003/3312). All animal experiments were carried out in accordance with the regulations and guidelines of the Kenya Medical Research Institute.

\section{GenBank Accession Numbers}

The NPV genome was deposited in GenBank under accession nos. MF695810-MF695812. The COI sequence obtained from the virus-positive sand fly pool was deposited in GenBank under accession no. MG913288.

\section{Results}

\section{NPV Isolation and Characterization}

In total, 6,434 sand flies were trapped (Figure 1). A subset of 5,481 sandflies was pooled and the resulting 111 pools individually inoculated in VeroE6/7 cells. One pool consisting of 8 females induced CPE 4-5 days postinfection. Sequence analysis of the COI gene of the sand flies of this CPE-positive pool suggested that sand flies were of the genus Sergentomyia. We identified blood-meal hosts for 62 blood-fed specimens sampled at the same place and time as the pooled specimens. Results revealed that $56(90.3 \%)$ had fed on humans, $2(3.2 \%)$ on snakes, and $1(1.6 \%)$ each on a frog, lizard, cow, and ostrich. The infectious cell culture supernatant tested negative for RVFV, orthobunyaviruses, alphaviruses, and members of genus Flavivirus. We amplified a $0.5-\mathrm{kb}$ fragment of the RdRp gene of sand flyborne phleboviruses using degenerated primers (25). The sequence showed the highest pairwise identity of $79 \%$ to GFV and $75 \%$ to KARV. We sampled a subset of 953 individual sand fly samples 2 years after the initial study and 
tested it in pools of 10 by specific RT-PCR for the cultured virus; results were negative.

Analysis of the complete genome by next-generation sequencing confirmed isolation of a novel phlebovirus. The virus was tentatively termed Ntepes virus, after the location where the sand flies were collected. The virus exhibits the characteristic tripartite-segmented genome organization of phleboviruses, comprising the large (L) segment, which encodes the RdRp protein; the medium (M) segment, encoding a glycoprotein precursor protein (GPC) that is posttranslationally cleaved into 2 viral surface glycoproteins ( $\mathrm{Gn}$ and Gc) and a nonstructural protein (NSm); and the small (S) segment, encoding the nucleocapsid $(\mathrm{N})$ protein and a nonstructural protein (NS) in an ambisense manner (Figure 2). Highest sequence similarities to GFV were $93 \%$ to RdRp, $88 \%$ to GPC, $79 \%$ to Nsm, $85 \%$ to N, and $90 \%$ to NS. NPV has the typical conserved genome termini shared among phleboviruses (5'-ACACAAAG and CUUUGUGU-3') (8).
Phylogenetic analyses of NPV RdRp, Gn, Gc, and N proteins and all available sand fly-borne phlebovirus sequences indicate that NPV forms a strongly supported clade with GFV and KARV. NPV branches as a sister taxon to GFV in all genes, suggesting NPV to be a member of the Karimabad species complex (Figure 3). However, the designation of the Karimabad species complex is not yet officially approved by the ICTV. For a provisional genetic classification, we analyzed the intragenetic distances among established phlebovirus species and unclassified isolates based on the RdRp gene. Pairwise nucleotide and amino acid distances between established species ranged from $38 \%$ to $62 \%$ for nucleotide distances and $39 \%$ to $68 \%$ for amino acid distances (Appendix Figure, http://wwwnc.cdc.gov/EID/ article/25/4/18-0750-App1.pdf). For example, amino acid distance between Punta Toro virus and Candiru virus was $39 \%$ and between SFTS virus and sandfly fever Naples virus was $68 \%$. Pairwise nucleotide distances ranged from $20 \%$ to

\begin{tabular}{|c|c|c|c|c|c|c|c|c|}
\hline \multirow{2}{*}{$\begin{array}{l}\text { Sample } \\
\text { ID }\end{array}$} & \multirow[b]{2}{*}{ Origin } & \multirow{2}{*}{$\begin{array}{l}\text { Age, } \\
\text { y/sex }\end{array}$} & \multirow[b]{2}{*}{ Occupation } & \multirow[b]{2}{*}{ Acute febrile infection† } & \multicolumn{4}{|c|}{ Reactivity against } \\
\hline & & & & & NPV & RVFV & GBV & KARV \\
\hline $\mathrm{H} 01$ & Marigat & $8 / \mathrm{F}$ & Student & Fever/chills, head/joint/muscle aches & $1: 40$ & None & None & None \\
\hline $\mathrm{H} 02$ & Marigat & $10 / F$ & Student & $\begin{array}{l}\text { Fever/chills, cough, head/joint/muscle } \\
\text { aches, eye pain, diarrhea }\end{array}$ & $1: 20$ & None & None & None \\
\hline H03 & Marigat & $18 / F$ & Student & $\begin{array}{l}\text { Fever/chills, cough, head/joint/muscle } \\
\text { aches, jaundice, abdominal pain }\end{array}$ & $1: 40$ & None & None & None \\
\hline $\mathrm{H} 04$ & Marigat & $19 / \mathrm{M}$ & $\begin{array}{l}\text { Shop } \\
\text { attendant }\end{array}$ & $\begin{array}{l}\text { Acute febrile illness-fever/chills, } \\
\text { cough, head/muscle aches }\end{array}$ & $1: 20$ & None & None & None \\
\hline $\mathrm{H} 05$ & Marigat & 29/M & Driver & Fever/chills, head/joint/muscle aches & $1: 80$ & None & None & None \\
\hline H06 & Sangailu & $17 / F$ & Housewife & Fever & $1: 40$ & None & None & None \\
\hline $\mathrm{H} 07$ & Sangailu & 25/M & Herdsman & Fever/chills, headache, diarrhea & $1: 320$ & $1: 1,280$ & None & None \\
\hline $\mathrm{H} 08$ & Sangailu & $42 / F$ & Housewife & $\begin{array}{l}\text { Fever/chills, headache, } \\
\text { abdominal pain }\end{array}$ & $1: 40$ & None & None & None \\
\hline H09 & Sangailu & $50 / F$ & Housewife & $\begin{array}{c}\text { Fever/chills, cough, } \\
\text { head/joint/muscle aches }\end{array}$ & $1: 20$ & None & None & None \\
\hline $\mathrm{H} 10$ & Sangailu & $24 / \mathrm{M}$ & Herder & $\begin{array}{c}\text { Fever/chills, head/joint/muscle aches, } \\
\text { diarrhea }\end{array}$ & $1: 320$ & None & None & None \\
\hline $\mathrm{H} 11$ & Sangailu & $53 / F$ & Housewife & $\begin{array}{l}\text { Fever, cough, headache, } \\
\text { abdominal pain, muscle ache }\end{array}$ & $1: 20$ & None & None & None \\
\hline $\mathrm{H} 12$ & Sangailu & 26/M & Shepherd & Healthy control & $1: 20$ & None & None & None \\
\hline H13 & Sangailu & $30 / F$ & Housewife & Healthy control & $1: 160$ & None & None & None \\
\hline $\mathrm{H} 14$ & Sangailu & $65 / \mathrm{M}$ & Pastoralist & Healthy control & $1: 40$ & $1: 320$ & None & None \\
\hline H15 & Sangailu & $62 / \mathrm{M}$ & Herdsman & Healthy control & $1: 80$ & $1: 640$ & None & None \\
\hline H16 & Sangailu & $34 / F$ & Housewife & Healthy control & $1: 80$ & None & None & None \\
\hline $\mathrm{H} 17$ & Sangailu & $52 / F$ & Housewife & Healthy control & $1: 20$ & None & None & None \\
\hline H18 & Sangailu & $50 / \mathrm{M}$ & Herdsman & Healthy control & None & $1: 1,280$ & None & None \\
\hline H19 & Sangailu & $57 / \mathrm{M}$ & Herdsman & Healthy control & None & $1: 320$ & None & None \\
\hline $\mathrm{H} 20$ & Sangailu & $16 / \mathrm{M}$ & Herder & $\begin{array}{l}\text { Fever/chills, head/joint/muscle aches, } \\
\text { abdominal pain }\end{array}$ & $1: 160$ & $1: 160$ & None & None \\
\hline $\mathrm{H} 21$ & Sangailu & $18 / \mathrm{M}$ & Student & $\begin{array}{l}\text { Fever, cough, headache, } \\
\text { abdominal pains }\end{array}$ & $1: 80$ & None & None & None \\
\hline $\mathrm{H} 22$ & Sangailu & $9 / F$ & Student & $\begin{array}{l}\text { Fever/chills, cough, abdominal pains, } \\
\text { joint/muscle aches }\end{array}$ & $1: 160$ & None & None & None \\
\hline $\mathrm{H} 23$ & Sangailu & $19 / F$ & Housewife & $\begin{array}{l}\text { Fever/chills, headache } \\
\text { abdominal pains }\end{array}$ & $1: 40$ & None & None & None \\
\hline $\mathrm{H} 24$ & Sangailu & $30 / F$ & Housewife & $\begin{array}{c}\text { Fever, head/joint/muscle aches, } \\
\text { abdominal pain }\end{array}$ & $1: 160$ & $1: 40$ & None & None \\
\hline H25 & Sangailu & $17 / \mathrm{M}$ & Herder & $\begin{array}{l}\text { Fever/chills, head/joint/muscle aches, } \\
\text { abdominal pain }\end{array}$ & $1: 160$ & None & None & None \\
\hline $\mathrm{H} 26$ & Marigat & $17 / \mathrm{M}$ & Student & Fever/chills, head/joint/muscle aches & $1: 40$ & None & None & None \\
\hline
\end{tabular}

*GFV, Gabek Forest virus; ID, identification; KARV, Karimabad virus; NPV, Ntepes virus; NT, neutralizing test; RVFV, Rift Valley fever virus. $\dagger$ Fever defined as body temperature $\geq 38^{\circ} \mathrm{C}$. 
$59 \%$ and amino acid distances from $6 \%$ to $69 \%$ when unclassified tentative species and variants pertaining to established species were included. For example, amino acid distance between Ponticelli virus and Adana virus was $6 \%$ and between Naples virus and SFTS virus was 69\% (Appendix Figure). NPV showed $7 \%$ amino acid distance to GFV and 19\% amino acid distance to KARV.

Classical criteria for species demarcation in phleboviruses are based on serology, with established species showing at least 4-fold differences in 2-way neutralization tests (11). We confirmed that NPV did not react with antiserum against its next closest relatives, GFV and KARV, in neutralization tests (Figure 4). NPV Gn protein was 13\% different and Gc 4\% different from GFV. The Gn protein of phleboviruses is the key component for neutralization and is recognized by specific neutralizing antibodies (33).

Although sequence-based species demarcation criteria have not been determined for phlebovirus species, such criteria exist for the related orthobunyaviruses. Species demarcation criteria are now based on the RdRp gene, which shows $\geq 6 \%$ difference to the closest related virus. Previously unique orthobunyavirus species were defined on $\geq 10 \%$ difference in $\mathrm{N}$ protein sequences (11). The $\mathrm{N}$ proteins of NPV and GFV differ by $15 \%$ (GFV itself is not formally classified as a species, and any of the formally classified phlebovirus species are markedly more distant from NPV in this and other genes; Appendix Figure). We conclude, upon cumulative evidence, that NPV constitutes a putative novel species within the phlebovirus genus.

\section{Permissiveness in Vertebrates}

To obtain initial data on permissiveness, we performed in vitro growth analyses in a broad range of cell lines derived from different insect species (sand fly and mosquito), peridomestic wildlife (rodent, nonhuman primate, and bat), and livestock (swine, goat, chicken, and cattle) species, as well as from humans. Results revealed a broad susceptibility to NPV, with peak genome copy numbers in cells derived from swine and rodents (Figure 5, panel A). Cells derived from sand flies but not from mosquitoes were permissive, despite using C6/36 mosquito cells that are normally broadly susceptible to arboviruses because of a defect in their antiviral RNA interference response (34). These findings suggest a host range for NPV similar to those of KARV and GFV, which are transmitted by sand flies and infect rodents (35). It is not known whether rodents are amplificatory or dead-end hosts.

Because GFV is known to induce fatal disease in laboratory mice $(36,37)$, we explored similarities in pathogenicity with NPV. We intracranially inoculated 3-4-day-old Swiss Albino suckling mice, causing tremors, hind-limb paralysis, prostration, and death 5-8 days postinfection (Figure 5, panel B). Time to death was clearly correlated with virus dose. All animals had high infectious virus concentrations in the brain (mean $2.9 \times 10^{6} \mathrm{PFU} / \mathrm{mL}$ ). Taken together, the in vitro and in vivo pathogenicity studies of $\mathrm{NPV}$, including the pathogenicity in suckling mice, may suggest that rodents and sand flies may be involved in the maintenance cycle of NPV.

\section{Evidence for Human Infection with NPV}

To test whether NPV infects humans, we analyzed 187 archived serum samples: 59 samples from the Marigat district hospital in the area where NPV-infected sand flies were trapped, and 128 samples collected in northeastern Kenya at Sangailu Health Centre (Figure 1). All
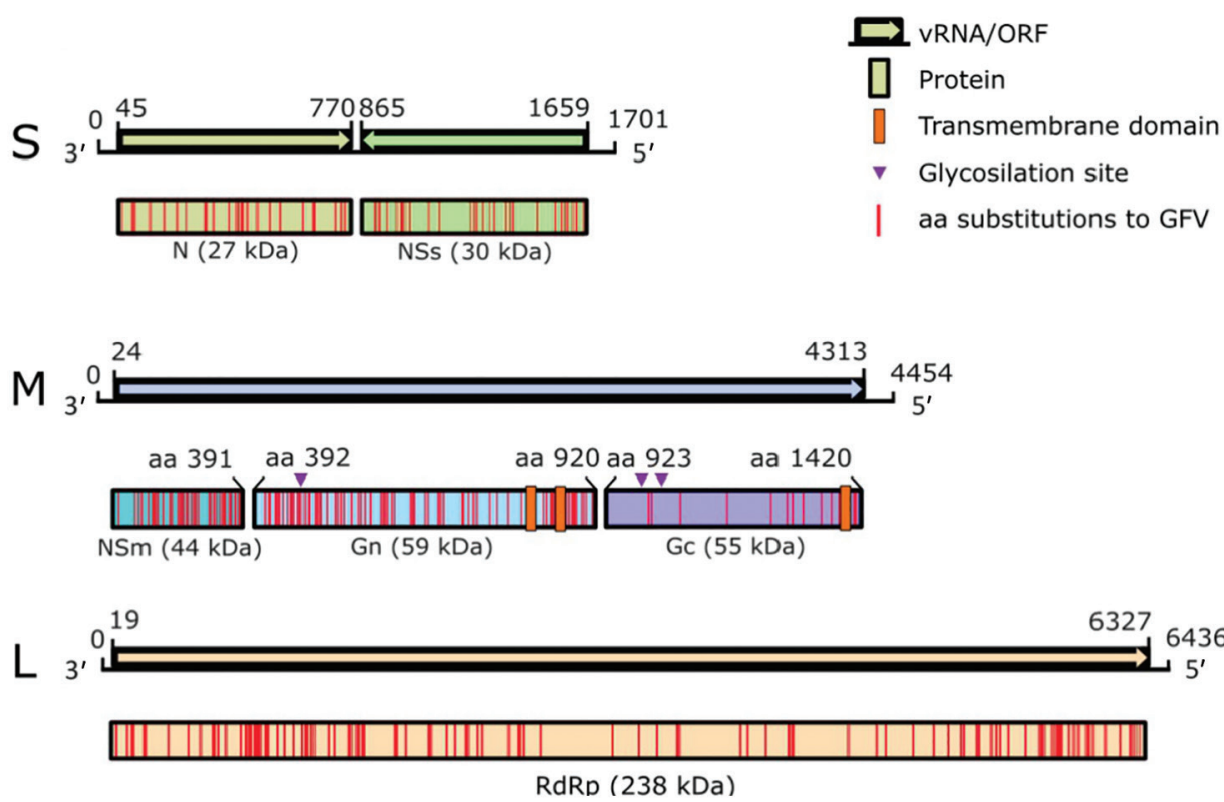

Figure 2. Genome organization of novel sand fly-associated phlebovirus Ntepes virus identified in Kenya. Sequence length of the $\mathrm{L}, \mathrm{M}$, and $\mathrm{S}$ segments (in bp) and encoded predicted proteins RdRp, $\mathrm{Gn}, \mathrm{Gc}, \mathrm{N}$, and nonstructural proteins NSm and NSs (in $\mathrm{kDa}$ ) are indicated; ORF positions (length in bp) are also indicated. GFV, Gabek Forest virus; L, large segment (encoding the RdRp protein); $\mathrm{M}$, medium segment (encoding the nonstructural protein NSm and the 2 glycoproteins Gn and $\mathrm{Gc}$ ); N, nucleocapsid protein; ORF, open reading frame; RdRp, RNA-dependent RNA polymerase; $\mathrm{S}$, small segment (encoding the $\mathrm{N}$ protein and nonstructural protein NSs in an ambisense manner); vRNA, virus RNA. 

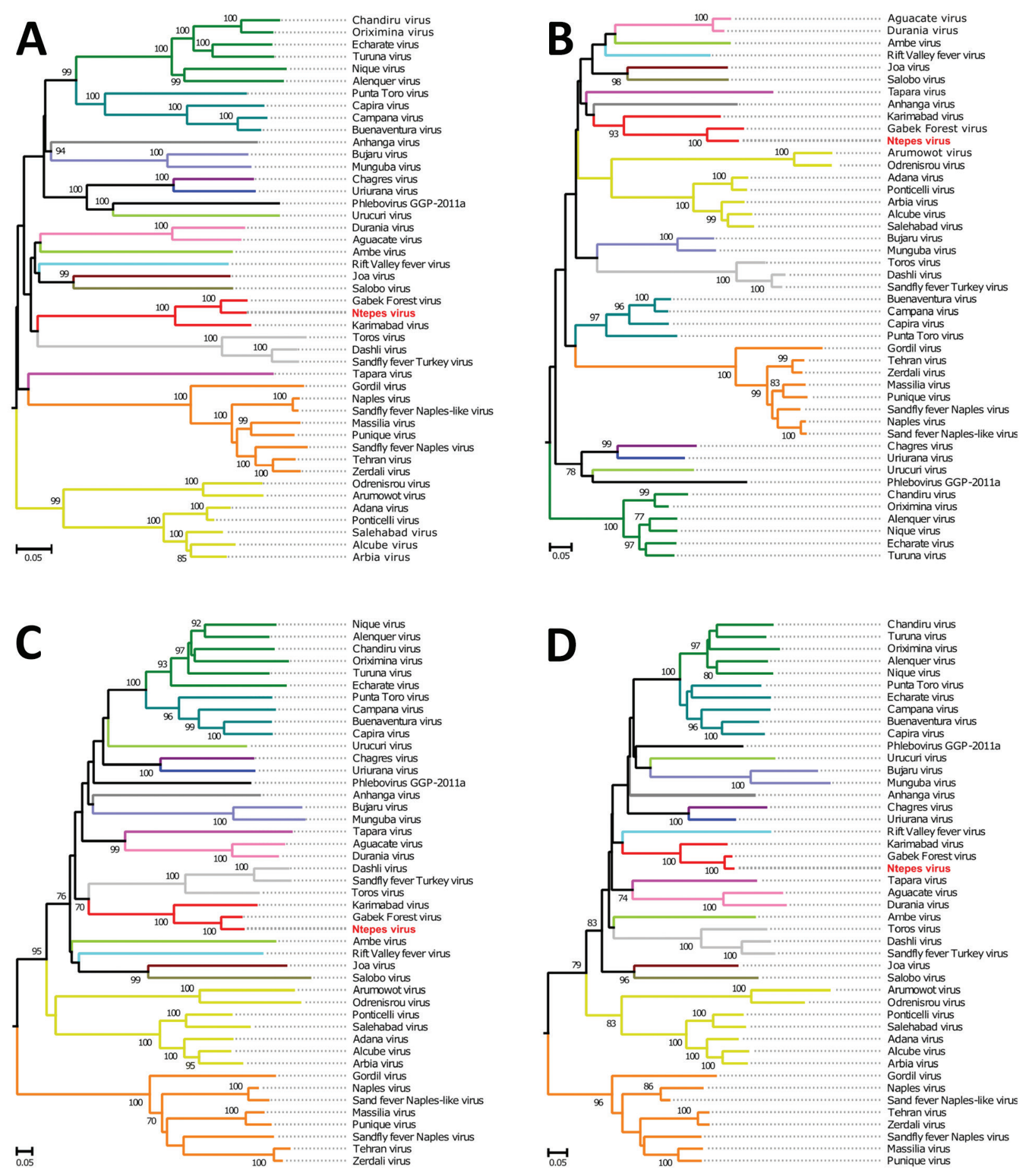

$\square$ Aguacate $\square$ Anhanga $\square$ Candiru $\square$ Frijoles $\square$ Karimabad $\square$ Rift Valley $\square$ Sandfly Fever Naples $\square$ Tapera
Ambe $\square$ Bujaru $\square$ Chagres $\square$ Icoarci $\square$ Punta Toro $\square$ Salehabad $\square$ Sandfly Sicilian Turkey $\square$ Urucuri

Figure 3. Phylogenetic relationship of novel sand fly-associated phlebovirus Ntepes virus from Kenya (red bold text) in relation to other selected members of the Phlebovirus genus. A) RNA-dependent RNA polymerase; B) nucleocapsid protein; C) glycoprotein Gn; D) glycoprotein $\mathrm{Gc}$. The phylogenetic trees were inferred based on complete large, medium, and small protein sequences, applying maximum likelihood analysis in PhyML version 3.0 (http://www.atgc-montpellier.fr/phyml/versions.php) using the LG substitution model. Statistical support of the tree topology was evaluated by bootstrap resampling of the sequences 1,000 times. Sequences are identified by virus name and branch colors. Bootstrap values $>70$ are indicated at the nodes. Scale bar represents numbers of substitutions per site. 


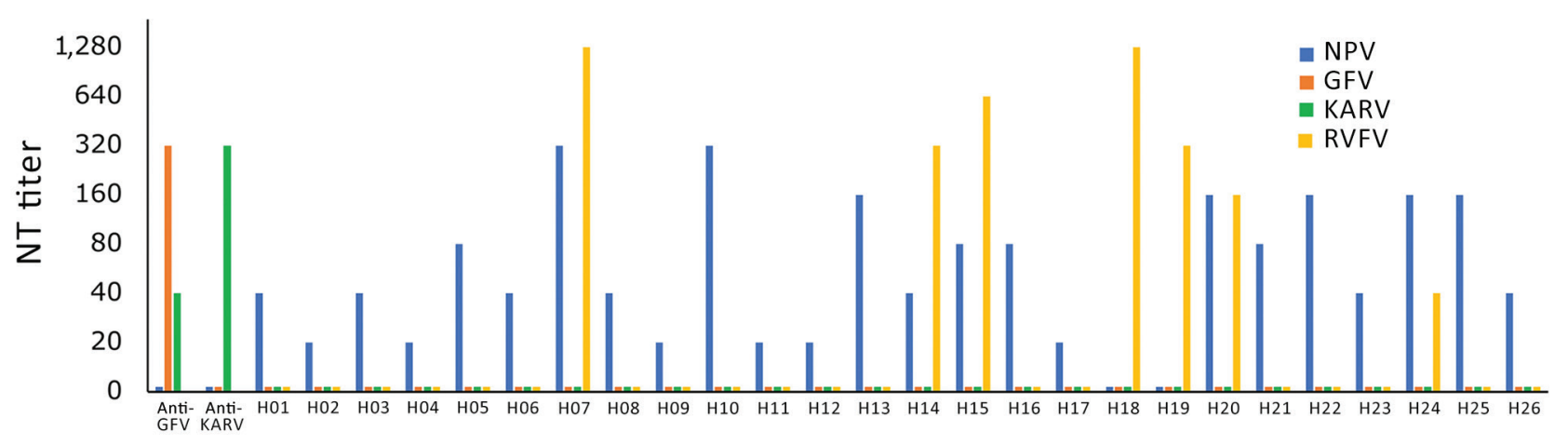

Figure 4. Neutralizing activity of novel sand fly-associated phlebovirus Ntepes virus from Kenya in relation to other selected members of the Phlebovirus genus. Anti-GFV and anti-KARV samples were tested along with 26 human serum samples. GFV, Gabek Forest virus; $\mathrm{H}$, human; KARV, Karimabad virus; NPV, Ntepes virus; NT, neutralizing test; RVFV, Rift Valley fever virus.

patients from Marigat, as well as 98 patients from Sangailu, had symptoms compatible with acute infectious diseases. The remaining 30 samples from Sangailu came from healthy controls.

Twenty-six (13.9\%) serum samples neutralized NPV, with titers ranging from 1:20 to 1:320 (Figure 4). Women and men were infected at equal rates. Positive samples originated from Marigat (10.2\%) and Sangailu (15.6\%), without statistical differences in rates (Fisher exact test odds ratio [OR] 0.6, 95\% CI 0.19-1.70; $\mathrm{p}=0.37$ ). Detection rates in Sangailu did not differ between healthy and febrile patients (Fisher exact test OR 1.4, 95\% CI 0.40-4.3; p = 0.58) (Table; Figure 4). No NPV nucleic acids were detected in serum samples by NPV-specific RT-PCR, suggesting no causative link to the present symptoms with NPV. The detection of NPV neutralizing antibodies in geographically unlinked regions of Kenya suggests widespread previous human exposure and infection.

Because NPV is genetically most closely related to GFV and KARV, we tested all NPV-positive serum samples for ability to cross-neutralize GFV or KARV. All tests yielded negative results, providing further support for the classification of NPV as a separate serotype (and species). Because RVFV frequently causes outbreaks in East Africa, we also tested against RVFV, which, according to its phylogenetic relationship with NPV, is not expected to cross-react with NPV. Seven of 26 NPV-neutralizing serum samples were also reactive with RVFV, showing titers that did not correlate in height with titers against NPV (Table; Figure 4). Absence of correlation of titers suggests previous RVFV infection rather than cross-reactivity between RVFV and NPV.

\section{Discussion}

We identified a high percentage of neutralizing antibodies to NPV in humans living in the NPV-endemic area by neutralization assay, confirming that NPV represents a distinct phleboviral species that causes infection in humans. The fact that the virus was isolated through an exploratory sampling effort is an indicator of the existence of undetected and uncharacterized viruses in this part of Kenya. Although mosquitoes have been the focus of studies on emerging arboviruses, the discovery of a novel sand fly-borne phlebovirus with evidence for human exposure across Kenya indicates the need to broaden vector surveillance activities.

Toscana, sandfly fever Sicilian, and sandfly fever Naples viruses are distributed in the Mediterranean region and northern Africa. GFV has been reported from Sudan, Senegal, Central African Republic, Nigeria, and Benin (38). KARV occurs in eastern and central Asia $(7,39,40)$, as well as Sudan, Egypt, and Nigeria (7). According to this geographic distribution, GFV seems to be the most likely sand fly-borne phlebovirus to co-occur in Kenya. Our results show that NPV-immune serum samples do not react with GFV or KARV, suggesting that the reactivity of the positive human samples was the result of previous infection with NPV.

NPV in Kenya may occupy a niche that is taken by GFV and KARV in northern Africa or eastern and central Asia. Several characteristics of NPV suggest parallels between the host ranges of NPV and GFV. GFV has been detected in rodents (38) but has been detected in arthropods in only a single study in sand flies (35). Further, the virus was shown to be able to infect Phlebotomus species under laboratory conditions (Tesh R. Studies of the biology of phleboviruses in sand flies. Paper presented at Yale University School of Medicine, New Haven, CT, USA, 1983), suggesting that GFV is maintained in a transmission cycle that involves rodents and sand flies and that it occasionally infects humans (35). NPV was isolated from sand flies and replicates in vitro in sand fly-derived cell lines but not in mosquito cells, similar to sandfly Sicilian and Naples viruses (41). Infection studies with cell lines derived from livestock and peridomestic wildlife species showed that NPV replicates $\approx 10-100$ times better in rodent and swine cell 
lines than in cells derived from other animals, suggesting the involvement of rodents or swine as potential amplificatory hosts for NPV.

COI gene analyses from the virus-positive sand fly pool suggests that species of the genus Sergentomyia have been infected with NPV. Blood-meal analyses revealed that $90 \%$ of the analyzed blood-fed sand flies had fed on humans, confirming a likely role as vectors of NPV to humans. Our findings provide new evidence that Sergentomyia flies do not strictly feed on reptiles but also feed frequently on humans $(42,43)$.

The NPV antibody prevalence rate in humans $(13.9 \%)$ is comparable to that of GFV, which is $17 \%-$ $60 \%$ in Sudan, 3\%-10\% in Egypt, and 3\% in Nigeria (7). KARV antibody prevalence is $1 \%-11 \%$ in Sudan, $2 \%$ in Egypt, and 1\%-62\% in regions of Iran and Russia (7). Human serum samples from northern Kenya have been tested and yielded no antibodies against GFV or KARV, which matches our results (7).

NPV appears to have a wide distribution in Kenya; we found equal exposure rates in 2 geographic sets of humans sampled $>600 \mathrm{~km}$ apart. The serum samples from this study were collected during 2010-2012, suggesting that NPV has been present in humans since at least 2010 . Sand fly pools collected in 2014 had low infection rates (MIR 0.18, 1/111 pools, 5-50 sand flies/pool), possibly resulting from collection during a period with low transmission rates. The estimated MIR is lower compared with previous sand fly infections with phleboviruses such as Punique (MIR 6.7) (14), Massilia (MIR 3.7) (12), and Toscana (MIR 2.2) viruses (44), although comparable to Toros (MIR 0.26) and Zerdali (MIR 0.35) viruses (45). The significance of just 1 isolate of the novel phlebovirus from 111 sand fly pools may seem limited, but it is noteworthy that circulation of RVFV, a phlebovirus with huge epidemic potential, is generally detected at low rates in vectors during interepidemic periods. For instance, multiple surveillance efforts sampling and analyzing thousands of primary and secondary RVFV vectors from outbreak hotspot areas failed to yield any RVFV isolates $(46,47)$, yet RVFV infection rates in mosquitoes during the 20062007 outbreak in Kenya were high, ranging between 0.8 and 10.65 per 1,000 for primary vectors (2).

The outcome of infection experiments in mice suggests that NPV could cause diseases such as GFV and RVFV infection $(36,37)$. The neglect of sand fly-borne phleboviruses in Africa is exemplified by outbreaks of acute febrile illness associated with sandfly fever Sicilian virus in Ethiopia, which, for a long time, had remained misdiagnosed as malaria (48), as well as an outbreak of febrile illness probably associated with sandfly fever $\mathrm{Na}-$ ples virus in Sudan (17).

The symptoms reported among most of the tested patients in this study cannot be conclusively linked to NPV
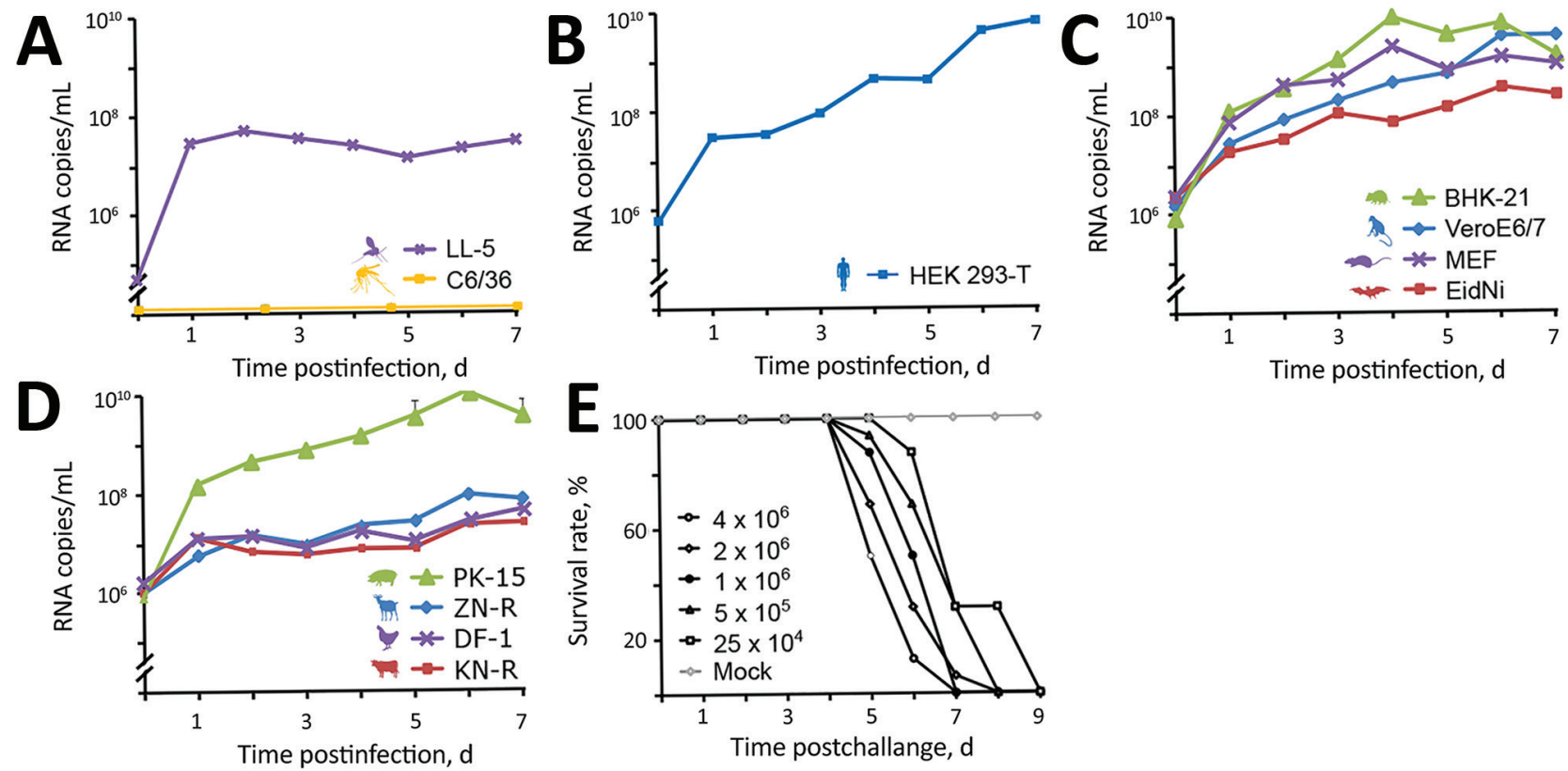

Figure 5. In vitro growth kinetics of novel sand fly-associated phlebovirus Ntepes virus from Kenya in different cell lines. A) Insects: LL-5, sand fly; C6/36, mosquito. B) Human: HEK293-T. C) Peridomestic wildlife: hamster, BHK-21; primate, VeroE6/7; mouse, MEF; bat, EidNi. D) Livestock: swine, PK-15; goat, ZN-R; chicken, DF-1; cattle, KN-R. Cells were infected with a multiplicity of infection of 0.1 ; supernatants were collected every $24 \mathrm{~h}$ for $7 \mathrm{~d}$ postinfection. Viral genome copies were measured at indicated timepoints by real-time reverse transcription PCR. E) Pathogenicity of Ntepes virus infection in mice. Litters of 2-day-old Swiss Albino suckling mice (8 mice/ litter) were intracerebrally inoculated using the indicated virus titers or cell culture media as a control. Animals were monitored daily for signs of disease. Titers are shown in PFU/mL. 
infection, as indicated by antibodies in symptomatic patients and healthy controls, demanding further studies of possible disease association. Clinical studies using specific real-time PCR are necessary to detect viral RNA in humans and to measure the clinical impact of NPV.

\section{Acknowledgments}

We thank Mark Rotich for logistical support during field collection of sandflies in Marigat district and Robinson Okiro and Julia Wanjiru for support in the laboratory to sort and pool sand fly samples. Special thanks to John Gachoya for help in mice inoculation, Jackson Kimani for GIS design of the map of the study sites, and the chief and community members at Ntepes for their cooperation and support. We thank Diane E. Griffin and Armanda D.S. Bastos for critical review of the manuscript.

The research is an output from an International Centre of Insect Physiology and Ecology seed grant, awarded to D.P.T. and B.T. D.P.T. also received postdoctoral support through the International Centre of Insect Physiology and Ecology from the UK Department for International Development and the Swedish International Development Cooperation Agency. We also acknowledge financial support from the Swiss Agency for Development and Cooperation and the Kenya government. Work at Charité Berlin was funded by the German Center for Infection Research (grant no. TTU 01.801) as well as by the Deutsche Forschungsgemeinschaft (grant nos. JU 2857/9-1 [to S.J.] and BO 1116/8-1).

\section{About the Author}

Dr. Tchouassi is a disease vector ecologist working as a research scientist at the International Centre of Insect Physiology and Ecology, Nairobi, Kenya. His research interest is in developing and evaluating complementary innovative vector control tools and monitoring of pathogen-vector dynamics for epidemiological assessments.

\section{References}

1. Sang RC, Dunster LM. The growing threat of arbovirus transmission and outbreaks in Kenya: a review. East Afr Med J. 2001;78:655-61. http://dx.doi.org/10.4314/eamj.v78i12.8936

2. Sang R, Kioko E, Lutomiah J, Warigia M, Ochieng C, O'Guinn M, et al. Rift Valley fever virus epidemic in Kenya, 2006/2007: the entomologic investigations. Am J Trop Med Hyg. 2010;83 (Suppl):28-37. http://dx.doi.org/10.4269/ajtmh.2010.09-0319

3. Wilder-Smith A, Gubler DJ, Weaver SC, Monath TP, Heymann DL, Scott TW. Epidemic arboviral diseases: priorities for research and public health. Lancet Infect Dis. 2017;17:e101-6. http://dx.doi.org/10.1016/S1473-3099(16)30518-7

4. Junglen S, Drosten C. Virus discovery and recent insights into virus diversity in arthropods. Curr Opin Microbiol. 2013;16:507-13. http://dx.doi.org/10.1016/j.mib.2013.06.005

5. Maroli M, Feliciangeli MD, Bichaud L, Charrel RN, Gradoni L. Phlebotomine sandflies and the spreading of leishmaniases and other diseases of public health concern. Med Vet Entomol. 2013; 27:123-47. http://dx.doi.org/10.1111/j.1365-2915.2012.01034.x
6. Alkan C, Bichaud L, de Lamballerie X, Alten B, Gould EA, Charrel RN. Sandfly-borne phleboviruses of Eurasia and Africa: epidemiology, genetic diversity, geographic range, control measures. Antiviral Res. 2013;100:54-74. http://dx.doi.org/ 10.1016/j.antiviral.2013.07.005

7. Tesh RB, Saidi S, Gajdamovič SJ, Rodhain F, Vesenjak-Hirjan J. Serological studies on the epidemiology of sandfly fever in the Old World. Bull World Health Organ. 1976;54:663-74.

8. Elliott RM, Brennan B. Emerging phleboviruses. Curr Opin Virol. 2014;5:50-7. http://dx.doi.org/10.1016/j.coviro.2014.01.011

9. Tesh RB. The genus Phlebovirus and its vectors. Annu Rev Entomol. 1988;33:169-81. http://dx.doi.org/10.1146/ annurev.en.33.010188.001125

10. Charrel RN, Gallian P, Navarro-Marí J-M, Nicoletti L, Papa A, Sánchez-Seco MP, et al. Emergence of Toscana virus in Europe. Emerg Infect Dis. 2005;11:1657-63. http://dx.doi.org/10.3201/ eid1111.050869

11. Maes P, Adkins S, Alkhovsky SV, Avšič-Županc T, Ballinger MJ, Bente DA, et al. Taxonomy of the order Bunyavirales: second update 2018. Arch Virol. 2019. http://dx.doi.org/10.1007/ s00705-018-04127-3 [epub ahead of print]

12. Charrel RN, Moureau G, Temmam S, Izri A, Marty P, Parola P, et al. Massilia virus, a novel Phlebovirus (Bunyaviridae) isolated from sandflies in the Mediterranean. Vector Borne Zoonotic Dis. 2009;9:519-30. http://dx.doi.org/10.1089/ vbz.2008.0131

13. Collao X, Palacios G, de Ory F, Sanbonmatsu S, Pérez-Ruiz M, Navarro JM, et al. Granada virus: a natural phlebovirus reassortant of the sandfly fever Naples serocomplex with low seroprevalence in humans. Am J Trop Med Hyg. 2010;83:760-5. http://dx.doi.org/ 10.4269/ajtmh.2010.09-0697

14. Zhioua E, Moureau G, Chelbi I, Ninove L, Bichaud L, Derbali M, et al. Punique virus, a novel phlebovirus, related to sandfly fever Naples virus, isolated from sandflies collected in Tunisia. J Gen Virol. 2010;91:1275-83. http://dx.doi.org/10.1099/vir.0.019240-0

15. Remoli ME, Fortuna C, Marchi A, Bucci P, Argentini C, Bongiorno $\mathrm{G}$, et al. Viral isolates of a novel putative phlebovirus in the Marche Region of Italy. Am J Trop Med Hyg. 2014;90:760-3. http://dx.doi.org/10.4269/ajtmh.13-0457

16. Ayhan N, Charrel RN. Of phlebotomines (sandflies) and viruses: a comprehensive perspective on a complex situation. Curr Opin Insect Sci. 2017;22:117-24. http://dx.doi.org/10.1016/ j.cois.2017.05.019

17. Watts DM, El-Tigani A, Botros BA, Salib AW, Olson JG, McCarthy M, et al. Arthropod-borne viral infections associated with a fever outbreak in the Northern Province of Sudan. J Trop Med Hyg. 1994;97:228-30.

18. McCarthy MC, Haberberger RL, Salib AW, Soliman BA, | El-Tigani A, Khalid IO, et al. Evaluation of arthropod-borne viruses and other infectious disease pathogens as the causes of febrile illnesses in the Khartoum Province of Sudan. J Med Virol. 1996;48:141-6. http://dx.doi.org/10.1002/ (SICI)1096-9071(199602)48:2<141::AID-JMV4>3.0.CO;2-9

19. Rodhain F, Gonzalez J-P, Mercier E, Helynck B, Larouze B, Hannoun C. Arbovirus infections and viral haemorrhagic fevers in Uganda: a serological survey in Karamoja district, 1984. Trans R Soc Trop Med Hyg. 1989;83:851-4. http://dx.doi.org/ 10.1016/0035-9203(89)90352-0

20. Reed LJ, Muench H. A simple method of estimating fifty per cent endpoints. Am J Epidemiol. 1938;27:493-7. http://dx.doi.org/10.1093/oxfordjournals.aje.a118408

21. Kuno G, Mitchell CJ, Chang GJ, Smith GC. Detecting bunyaviruses of the Bunyamwera and California serogroups by a PCR technique. J Clin Microbiol. 1996;34:1184-8.

22. Kuno G, Chang G-JJ, Tsuchiya KR, Karabatsos N, Cropp CB. Phylogeny of the genus Flavivirus. J Virol. 1998;72:73-83. 
23. Shoemaker T, Boulianne C, Vincent MJ, Pezzanite L, Al-Qahtani MM, Al-Mazrou Y, et al. Genetic analysis of viruses associated with emergence of Rift Valley fever in Saudi Arabia and Yemen, 2000-01. Emerg Infect Dis. 2002;8:1415-20. http://dx.doi.org/10.3201/eid0812.020195

24. Eshoo MW, Whitehouse CA, Zoll ST, Massire C, Pennella T-TD, Blyn LB, et al. Direct broad-range detection of alphaviruses in mosquito extracts. Virology. 2007;368:286-95. http://dx.doi.org/10.1016/j.virol.2007.06.016

25. Sánchez-Seco MP, Echevarría JM, Hernández L, Estévez D, Navarro-Marí JM, Tenorio A. Detection and identification of Toscana and other phleboviruses by RT-nested-PCR assays with degenerated primers. J Med Virol. 2003;71:140-9. http://dx.doi.org/10.1002/jmv.10465

26. Tamura K, Stecher G, Peterson D, Filipski A, Kumar S. MEGA6: molecular evolutionary genetics analysis version 6.0. Mol Biol Evol. 2013;30:2725-9. http://dx.doi.org/10.1093/molbev/mst197

27. Folmer O, Black M, Hoeh W, Lutz R, Vrijenhoek R. DNA primers for amplification of mitochondrial cytochrome $\mathrm{c}$ oxidase subunit I from diverse metazoan invertebrates. Mol Mar Biol Biotechnol. 1994;3:294-9.

28. Roca AL, Bar-Gal GK, Eizirik E, Helgen KM, Maria R, Springer MS, et al. Mesozoic origin for West Indian insectivores. Nature. 2004;429:649-51. http://dx.doi.org/10.1038/nature02597

29. Valinsky L, Ettinger G, Bar-Gal GK, Orshan L. Molecular identification of bloodmeals from sand flies and mosquitoes collected in Israel. J Med Entomol. 2014;51:678-85. http://dx.doi.org/10.1603/ME13125

30. Katoh K, Misawa K, Kuma K, Miyata T. MAFFT: a novel method for rapid multiple sequence alignment based on fast Fourier transform. Nucleic Acids Res. 2002;30:3059-66. http://dx.doi.org/10.1093/nar/gkf436

31. Guindon S, Gascuel O. A simple, fast, and accurate algorithm to estimate large phylogenies by maximum likelihood. Syst Biol. 2003;52:696-704. http://dx.doi.org/10.1080/10635150390235520

32. Agha SB, Chepkorir E, Mulwa F, Tigoi C, Arum S, Guarido MM, et al. Vector competence of populations of Aedes aegypti from three distinct cities in Kenya for chikungunya virus. PLoS Negl Trop Dis. 2017;11:e0005860. http://dx.doi.org/10.1371/ journal.pntd.0005860

33. Wu Y, Zhu Y, Gao F, Jiao Y, Oladejo BO, Chai Y, et al. Structures of phlebovirus glycoprotein $\mathrm{Gn}$ and identification of a neutralizing antibody epitope. Proc Natl Acad Sci U S A. 2017;114:E7564-73. http://dx.doi.org/10.1073/pnas.1705176114

34. Brackney DE, Scott JC, Sagawa F, Woodward JE, Miller NA, Schilkey FD, et al. C6/36 Aedes albopictus cells have a dysfunctional antiviral RNA interference response. PLoS Negl Trop Dis. 2010;4:e856. http://dx.doi.org/10.1371/journal.pntd.0000856

35. Traoré-Lamizana M, Fontenille D, Diallo M, Bâ Y, Zeller HG, Mondo M, et al. Arbovirus surveillance from 1990 to 1995 in the Barkedji area (Ferlo) of Senegal, a possible natural focus of Rift Valley fever virus. J Med Entomol. 2001;38:480-92. http://dx.doi.org/10.1603/0022-2585-38.4.480

36. Tesh RB, Duboise SM. Viremia and immune response with sequential phlebovirus infections. Am J Trop Med Hyg. 1987;36:662-8. http://dx.doi.org/10.4269/ajtmh.1987.36.662

37. Fisher AF, Tesh RB, Tonry J, Guzman H, Liu D, Xiao S-Y. Induction of severe disease in hamsters by two sandfly fever group viruses, Punta toro and Gabek Forest (Phlebovirus, Bunyaviridae), similar to that caused by Rift Valley fever virus. Am J Trop Med Hyg. 2003;69:269-76. http://dx.doi.org/10.4269/ajtmh.2003.69.269

38. Kemp GE, Causey OR, Setzer HW, Moore DL. Isolation of viruses from wild mammals in West Africa, 1966-1970. J Wildl Dis. 1974;10:279-93. http://dx.doi.org/10.7589/0090-3558-10.3.279

39. Tesh R, Saidi S, Javadian E, Nadim A. Studies on the epidemiology of sandfly fever in Iran. I. Virus isolates obtained from Phlebotomus. Am J Trop Med Hyg. 1977;26:282-7. http://dx.doi.org/10.4269/ajtmh.1977.26.282

40. Gaidamovich SY, Khutoretskaya NV, Asyamov Y, Tsyupa V, Melnikova EE. Sandfly fever in central Asia and Afghanistan. In: Calisher $\mathrm{CH}$, editor. Hemorrhagic fever with renal syndrome, tickand mosquito-borne viruses. Vienna: Springer; 1991. p. 287-93.

41. Karabatos N. International catalogue of arboviruses including certain other viruses of vertebrates. 3rd ed. San Antonio (TX): American Society of Tropical Medicine and Hygiene; 1985.

42. Jaouadi K, Haouas N, Chaara D, Boudabous R, Gorcii M, Kidar A, et al. Phlebotomine (Diptera, Psychodidae) bloodmeal sources in Tunisian cutaneous leishmaniasis foci: could Sergentomyia minuta, which is not an exclusive herpetophilic species, be implicated in the transmission of pathogens? Ann Entomol Soc Am. 2013;106:7985. http://dx.doi.org/10.1603/AN11186

43. Maia C, Parreira R, Cristóvão JM, Freitas FB, Afonso MO, Campino L. Molecular detection of Leishmania DNA and identification of blood meals in wild caught phlebotomine sand flies (Diptera: Psychodidae) from southern Portugal. Parasit Vectors. 2015;8:173. http://dx.doi.org/10.1186/s13071-015-0787-4

44. Charrel RN, Izri A, Temmam S, Delaunay P, Toga I, Dumon H, et al. Cocirculation of 2 genotypes of Toscana virus, southeastern France. Emerg Infect Dis. 2007;13:465-8. http://dx.doi.org/ 10.3201/eid1303.061086

45. Alkan C, Erisoz Kasap O, Alten B, de Lamballerie X, Charrel RN. Sandfly-borne phlebovirus isolations from Turkey: New insight into the sandfly fever Sicilian and sandfly fever Naples species. PLoS Negl Trop Dis. 2016;10:e0004519. http://dx.doi.org/10.1371/ journal.pntd.0004519

46. Ochieng C, Lutomiah J, Makio A, Koka H, Chepkorir E, Yalwala S, et al. Mosquito-borne arbovirus surveillance at selected sites in diverse ecological zones of Kenya; 2007-2012. Virol J. 2013;10:140. http://dx.doi.org/10.1186/1743-422X-10-140

47. Sang R, Arum S, Chepkorir E, Mosomtai G, Tigoi C, Sigei F, et al. Distribution and abundance of key vectors of Rift Valley fever and other arboviruses in two ecologically distinct counties in Kenya. PLoS Negl Trop Dis. 2017;11:e0005341. http://dx.doi.org/10.1371/ journal.pntd.0005341

48. Woyessa AB, Omballa V, Wang D, Lambert A, Waiboci L, Ayele W, et al. An outbreak of acute febrile illness caused by sandfly fever Sicilian virus in the Afar region of Ethiopia, 2011. Am J Trop Med Hyg. 2014;91:1250-3. http://dx.doi.org/10.4269/ ajtmh.14-0299

Address for correspondence: David P. Tchouassi, International Centre of Insect Physiology and Ecology, Nairobi, Kenya; e-mail: dtchouassi@icipe.org; Sandra Junglen, Institute of Virology, CharitéUniversitätsmedizin Berlin, Charitéplatz 1, 10117 Berlin, Germany; e-mail: Sandra.junglen@charite.de 